\title{
Dual role of interferon- $\gamma$ signalling pathway in sensitivity of pancreatic beta cells to immune destruction
}

\author{
C. A. Gysemans ${ }^{1}$, D.Pavlovic ${ }^{2}$, R. Bouillon ${ }^{1}$, D. L. Eizirik ${ }^{2}$, C. Mathieu ${ }^{1}$ \\ ${ }^{1}$ Laboratory for Experimental Medicine and Endocrinology (LEGENDO), Katholieke Universiteit Leuven, Leuven, Belgium \\ ${ }^{2}$ Gene Expression Unit, Diabetes Research Center, Vrije Universiteit Brussel, Brussels, Belgium
}

\section{Abstract}

Aims/hypothesis. Disruption of the interferon-gamma (IFN- $\gamma$ ) signalling pathway at the level of interferon regulatory factor-1 (IRF-1) protects islets against cytokine-induced nitric oxide production and cell death in vitro. The aim of this study was to investigate the effects of a global disruption of IFN- $\gamma$ signalling, or a selective disruption of IRF-1, on beta-cell sensitivity to in vivo immune destruction.

Methods. In a first set of experiments, IFN- $\gamma$ receptor knockout mice (IFN- $\gamma \mathrm{R}^{--}$) and interferon regulatory factor-1 knockout mice (IRF-1 ${ }^{-/}$) were rendered diabetic by injections of $50 \mathrm{mg}$ streptozotocin i.p. on 5 consecutive days (MLDSTZ).

Results. Whereas no difference in sensitivity to MLDSTZ-induced diabetes could be observed between IFN- $\gamma \mathrm{R}^{-/}$mice and their $129 / \mathrm{Sv} / \mathrm{Ev}$ controls ( $50 \%$ vs $55 \%, \mathrm{NS})$, there was an increased incidence of diabetes in IRF-1- ${ }^{-/}$mice $(100 \%$ vs $67 \%$ in $\mathrm{C} 57 \mathrm{Bl} /$ 6 mice, $p<0.05)$. A similar increased sensitivity to immune destruction of IRF-1 $1^{-/-}$islets was observed when these islets were used as allografts. Islet graft survival rate of IFN- $\gamma \mathrm{R}^{-/-}$and $129 / \mathrm{Sv} / \mathrm{Ev}$ islets, when transplanted in alloxan-diabetic $\mathrm{BALB} / \mathrm{c}$ recipients, was comparable $(12.0 \pm 1.9$ days vs $12.9 \pm 2.3$ days, NS). Allograft rejection, however, of IRF-1 $1^{-/-}$islets by $\mathrm{BALB} / \mathrm{c}$ recipients occurred more rapidly than following transplantation to their $\mathrm{C} 57 \mathrm{Bl} / 6$ controls $(9.1 \pm 2.0$ days vs $13.1 \pm 1.5$ days, $p<0.003)$.

Conclusions/interpretation. These data indicate that IFN- $\gamma$ signal transduction at the beta-cell level is not essential for immune beta-cell destruction in vivo. Moreover, disruption of the IRF-1 gene in pancreatic islets increases susceptibility to beta-cell killing, suggesting that IRF-1 might be necessary for the expression of putative beta-cell "defence and/or repair" genes. [Diabetologia (2001) 44: 567-574]

Keywords Type I diabetes, cytokines, interferon regulatory factor-1, interferon- $\gamma$, signal transduction, islet destruction.
The ability of pancreatic islets to endure assaults of the immune system could be relevant in the development of Type I (insulin-dependent) diabetes mellitus. We and other investigators have suggested that inter-

Received: 13 September 2000 and in revised form: 18 January 2001

Corresponding author: Dr. Chantal Mathieu, LEGENDO, UZ Gasthuisberg O \& N, Herestraat 49, B-3000 Leuven, Belgium Abbreviations: iNOS, Inducible nitric oxide synthase; IFN- $\gamma$, interferon-gamma; IRF-1, interferon regulatory factor-1; IL, interleukin; MLDSTZ, multiple low dose streptozotocin; STAT, signal transducer and activator of transcription; STZ, streptozotocin. leukin-1 $\beta$ (IL-1 $\beta$ ) and other cytokines, especially interferon-gamma (IFN- $\gamma$ ) and tumor necrosis factor$\alpha$ (TNF- $\alpha)$ contribute to beta-cell dysfunction and death during early Type I diabetes [1-3]. Combinations of cytokines can contribute to beta-cell dysfunction in rodents by inducing inducible nitric oxide synthase (iNOS) expression, leading to the production of the radical nitric oxide [4-6]. Nitric oxide has been shown to cause Krebs cycle dysfunction and directly damage nuclear DNA in islet cells [7-10]. The presence of IL- $1 \beta$ is sufficient to induce iNOS transcription and nitric oxide formation in rodent islets, while a mixture of IL- $1 \beta$, IFN- $\gamma$ and TNF- $\alpha$ is required for iNOS mRNA expression in human islet cells [2]. 
These data suggest that IFN- $\gamma$ can play an important part in the development of diabetes. Indeed, islet infiltrating lymphocytes produce IFN- $\gamma$ during insulitis in animal models of Type I diabetes and administration of anti-IFN- $\gamma$ antibodies attenuates the development of the disease $[11,12]$.

Interferon-gamma activates a family of transcription factors known as the signal transducers and activators of transcription (STATs). Phosphorylation of STAT- $1 \alpha$ by the receptor-associated Janus kinase 1 and 2 (JAKs) in response to IFN- $\gamma$ results in STAT$1 \alpha$ homodimerization and nuclear translocation. Activated STAT- $1 \alpha$ complexes stimulate transcription of new genes by binding to gamma-activated site (GAS) elements in their promoter regions [13, 14]. One of these genes encodes interferon regulatory factor-1 (IRF-1) [15], a transcription factor involved in the induction of iNOS expression in pancreatic islet cells and known as a key player in the regulation of cell growth, apoptosis and function of a variety of immune effector cells [16-20].

It has been recently shown that IRF-1 mRNA expression is induced by IFN- $\gamma$, and to a minor degree by IL- $1 \beta$, and precedes iNOS expression and nitric oxide production in islets of rodent and human origin [16]. Moreover, by using the IRF-1 knockout mice $\left(\right.$ IRF-1 $\left.1^{-/}\right)$(a mouse with a targeted disruption of the IRF-1 gene) [21], our group has recently shown that in vitro exposure of whole IRF-1 $1^{-/}$islets to a mixture of cytokines led to a significant decrease in iNOS expression, nitric oxide formation and islet cell death [22]. On the other hand, FACS-purified IRF-1 $1^{-/}$beta cells were not protected against these deleterious effects of cytokines [22]. These in vitro findings suggest a relevant role for IRF-1 gene expression in islet nonbeta cells for cytokine-mediated destruction of beta cells in whole islets.

To further evaluate the role of IFN- $\gamma$, and especially IRF-1, as possible mediators of in vivo immune-mediated beta-cell destruction, we chose two genetically modified mouse models, namely the IFN- $\gamma$ receptor knockout mice (IFN- $\gamma \mathrm{R}^{-/}$) (a mouse deficient in the IFN- $\gamma$ receptor) and the IRF-1-1 (a mouse with a targeted disruption of the IRF-1 gene) mouse. We tested in these mice the susceptibility of beta cells towards immune destruction in multiple low dose streptozotocin (MLDSTZ)-induced diabetes and when transplanted in an allogeneic host.

\section{Materials and methods}

Animals. Breeding pairs of IRF-1/-- (3-times backcrossed into a $\mathrm{C} 57 \mathrm{Bl} / 6$ mice) were kindly provided by Dr. T. Mak of the Ontario Cancer Institute (Ontario, Canada). As wild-type controls, C57Bl/6 mice were used (Harlan CPB, Zeist, the Netherlands). IFN- $\gamma \mathrm{R}^{-/-}$and their controls $(129 / \mathrm{Sv} / \mathrm{Ev}$ mice) were kindly provided by Dr. P. Matthys. All animals were kept under semi-barrier conditions in the animal house of the Rega-
Institute (Leuven, Belgium). As recipients for islet grafting, we used 8 to 10 week-old BALB/c mice (Harlan CPB). All experimental designs were conducted with the approval of the Animal Ethics Committee of the Katholieke Universiteit Leuven.

MLDSTZ-induced diabetes. Streptozotocin (STZ) (Sigma Chemical, St. Louis, Mo., USA) was dissolved in $25 \mathrm{mmol} / \mathrm{l} \mathrm{ci-}$ trate buffer ( $\mathrm{pH} 4.5)$. Injections were made intraperitoneally $(50 \mathrm{mg} / \mathrm{kg})$ within $15 \mathrm{~min}$ of preparation. Male recipients (IRF-1 $1^{-/-}$IFN- $\gamma \mathrm{R}^{-/-}$and the respective controls) were treated with 5 consecutive daily injections [23] and development of glucosuria was monitored with Clinistix (Bayer Diagnostics, Tarrytown, N. Y., USA). Blood glucose was measured (Glucocard, Menarini, Firenze, Italy) in mice having glucosuria. A mouse was considered diabetic when measurements of blood glucose were higher than $11.0 \mathrm{~mol} / \mathrm{l}$ on two consecutive days. Mice were followed up until 45 days after the last injection of STZ. At that time point the animals were killed, and the pancreas removed for histology and insulin content measurement.

Islet allograft model. Islets from IRF- ${ }^{-/-}$, IFN $-\gamma \mathrm{R}^{-/-}$or of wildtype mice of each respective strain were isolated as described previously [24]. Briefly, pancreases of young mice were digested with collagenase in cold Hank's balanced salt solution by vigorous shaking. Islets were handpicked under a stereomicroscope. Islet recipients used were 8 to 10 -week-old BALB/c mice. One day before islet grafting, BALB/c mice were rendered diabetic by a single intravenous injection of $90 \mathrm{mg} / \mathrm{kg}$ alloxan (Fluka Chemika, Bornem, Belgium). Mice were anaesthetised by injection of avertin intraperitoneally $(0.02 \mathrm{ml} / \mathrm{mg}$ BW) (Fluka Chemika). The left kidney was exposed through a lumbar incision and recipient mice were transplanted with 500 fresh islets. Allograft function was followed by daily blood glucose measurements (Glucocard, Menarini, Firenze, Italy). Graft rejection was defined as measurements of blood glucose higher than $11.0 \mathrm{mmol} / \mathrm{l}$ on two consecutive days. Recipient mice were killed on the day of graft rejection or in a separate experiment for cytokine analysis in the graft on day 2 post transplantation. At that moment, the graft was removed for PCR analysis of infiltrating cytokines.

Histology and insulin content determination. In the MLDSTZmodel, pancreata were removed at the end of the experiment (45 days after STZ injection). One half of each pancreas was snap-frozen in liquid nitrogen and stored at $-80^{\circ} \mathrm{C}$ until processing. Serial cryostat sections ( $5 \mu \mathrm{m}$ thickness) were cut and stained with haematoxylin and eosin to assess pancreatic islet integrity [25]. Immunostaining was done with a polyclonal rabbit-anti-insulin antibody as previously described [26]. The beta-cell fraction in the islets from 5 pancreata per group (10 sections per pancreas) was analysed in a semi-quantitative blinded fashion. The insulin-positive surface of each individual islet was graded as percentage of the total islet surface $(>80$, $60-80,40-60,20-40$, or $<20 \%$ of insulin-positivity per islet). The remaining half of each pancreas was used for insulin content determination as described [25].

Total RNA extraction, $c D N A$ synthesis and real time RT-PCR analysis. In the allogeneic islet transplant model, total RNA was extracted from both islet graft and control kidney tissue (background level) using TRIzol reagent (Life Technologies, Gaithersburg, Md., USA) as described by the manufacturer. Target RNA $(5 \mu \mathrm{g})$ was reverse transcribed using $100 \mathrm{U}$ Superscript II RT (Life Technologies) at $42^{\circ} \mathrm{C}$ for $80 \mathrm{~min}$ in the presence of random primers. For each reaction set, one RNA sam- 


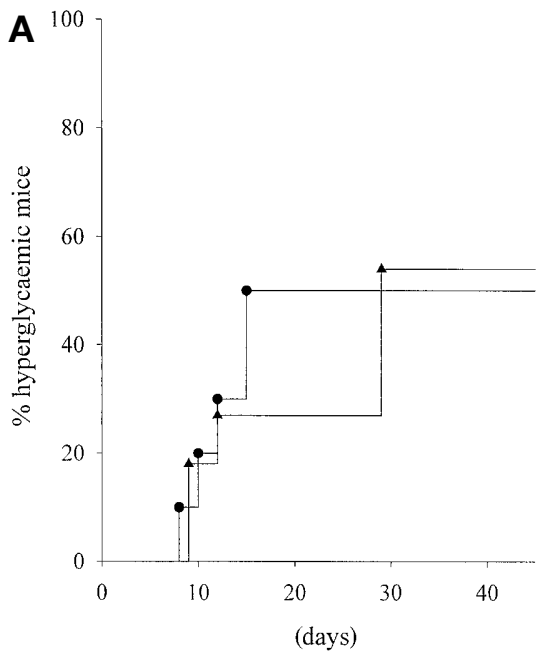

Fig. 1A, B. Multiple low-dose streptozotocin-(MLDSTZ)-induced diabetes in (A) IFN- $\gamma \mathrm{R}^{-1-}(n=10, \boldsymbol{O})$ and $129 / \mathrm{Sv} / \mathrm{Ev}$ $(n=11, \mathbf{\Delta})$ mice; (B) IRF- ${ }^{-1-}(n=13, \mathbf{\square})$ and $\mathrm{C} 57 \mathrm{Bl} / 6$ $(n=15, \boldsymbol{\nabla})$ mice. MLDSTZ-diabetes was induced in male mice as described under materials and methods. $* p<0.05$ vs STZ-treated C57Bl/6 control mice

ple was carried out without Superscript II RT ( $\mathrm{RT}^{-}$reaction) to provide a negative control in the subsequent PCR reactions.

For IL- $1 \beta$, TNF- $\alpha$, IFN- $\gamma$, IL-6, iNOS and the "house-keeping gene" $\beta$-actin, real time RT-PCR analysis of the islet grafts was done in the ABI prism 7700 Sequence detector (Perkin Elmer, Foster City, Calif., USA) as described previously [27]. Briefly, the PCR reactions contained in $25 \mu \mathrm{l}$ reaction solution: $1 \mu \mathrm{lDNA}, 100$ to $200 \mathrm{nmol} / \mathrm{l}$ of forward and reverse primers, $200 \mu \mathrm{mol} / \mathrm{l} \mathrm{dATP}, \mathrm{dCTP}, \mathrm{dGTP}$ and $400 \mu \mathrm{mol} / \mathrm{l} \mathrm{dUTP}, 2.5 \mu \mathrm{l}$ TaqMan Buffer A, 3 to $9 \mathrm{MgCl}_{2}, 0.25 \mathrm{U}$ AmpErase Uracil NGlycosylase and 0.625 units AmpliTaq Gold DNA polymerase (Perkin Elmer). Each reaction also contained $100 \mathrm{nmol} / \mathrm{l}$ of the corresponding probe and was done in triplicate wells, using the following conditions: $2 \mathrm{~min}$ at $50^{\circ} \mathrm{C}$ and $10 \mathrm{~min}$ at $94^{\circ} \mathrm{C}$, followed by a total of 40 to 45 two-temperature cycles $(15 \mathrm{~s}$ at $94^{\circ} \mathrm{C}$ and $1 \mathrm{~min}$ at $60^{\circ} \mathrm{C}$ ).

To enable comparisons between the amounts of target cDNA present in the different samples, we used external standards for each target cDNA, as well as for $\beta$-actin. To prepare these standards, plasmid clones containing a partial cDNA sequence of each target were constructed as described previously [27]. Serial dilutions of the resulting clones were used as standard curves each containing a known amount of input copy number. Cytokine mRNA expression was defined as a mean of cytokine copies/ $\beta$ actin copies.

Statistical analysis. Data are presented as means \pm standard deviation and statistical analysis was done using the chi-squared test for the incidence of MLDSTZ-induced diabetes, the logrank test for graft survival, the Student $t$ test for metabolic evaluation and the analysis of variance (ANOVA) for cytokine analysis. Statistical significance was defined as a $p$ value of less than 0.05 .

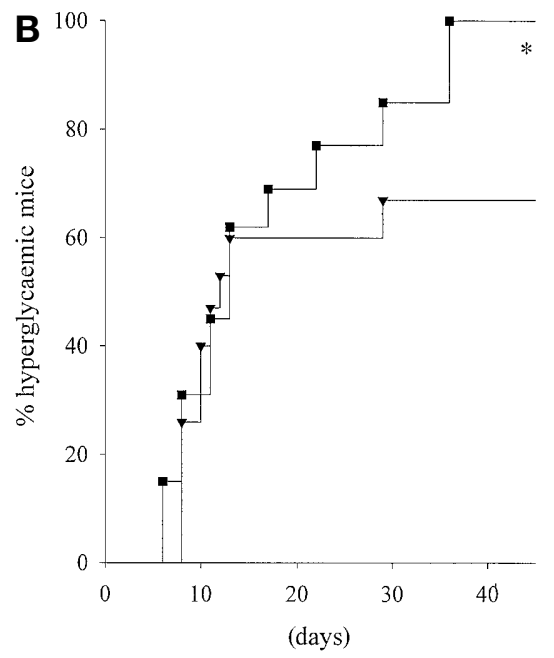

\section{Results}

MLDSTZ-induced diabetes. All experimental mice were sensitive to the hyperglycaemic action of MLDSTZ treatment. Diabetes incidence in full IFN$\gamma \mathrm{R}^{-1-}$ mice $(n=10)$ was not different from that of the $129 / \mathrm{Sv} / \mathrm{Ev}$ control mice $(n=11)(50 \%$ vs $55 \%, \mathrm{NS})$ (Fig.1). Interferon- $\gamma$ receptor knockout mice as well as $129 / \mathrm{Sv} / \mathrm{Ev}$ control mice became diabetic from 8 to 29 days after MLDSTZ injection. Surprisingly, all IRF-1 ${ }^{-/}$mice $(n=13)$ exposed to MLDSTZ injection became diabetic (100\%) compared to only 10 out of 15 of STZ-treated C57Bl/6 control mice (67\%, $p<0.05)$. Timing of diabetes onset was not different between IRF-1 $1^{-1}$ and C57B1/6 control mice (5 to 36 days after treatment with MLDSTZ).

Histological analysis of pancreata removed from IFN- $\gamma \mathrm{R}^{-1-}$ or $129 / \mathrm{Sv} / \mathrm{Ev}$ control mice at the end of the experiment showed comparable depletion of insulin positive beta cells in the few islets present. At this time point, little evidence remained of lymphocytes infiltrating into the residual insulin-depleted islets of both strains (data not shown). Pancreata from MLDSTZ-treated IRF-1 ${ }^{-/-}$mice clearly contained fewer islets, which were reduced in size and number of insulin positive beta cells, compared with MLDSTZ-treated C57B1/6 mice at day 45 after STZ injection (Fig. 2A-D). At this late time point hardly any lymphocyte infiltrates remained in either group. Semi-quantitative analysis of the pancreatic sections showed that in IFN- $\gamma \mathrm{R}^{-/}, 129 / \mathrm{Sv} / \mathrm{Ev}$ and C57Bl/ 6 mice, respectively $23,34,24 \%$ of the counted islets had an insulin-positive area of more than $50 \%$ of the islet, whereas in IRF-1 $1^{-/}$mice only $3 \%$ of the islets maintained insulin-positivity in more than $50 \%$ of their surface $(p<0.01$ vs STZ-treated control C57Bl/ 6 mice) (Table 1$)$.

At the end of the experiment, insulin content determinations in pancreata from diabetic mice with a full IFN- $\gamma$ receptor knockout or from $129 / \mathrm{Sv} / \mathrm{Ev}$ control mice showed no differences (Table 1). On the 

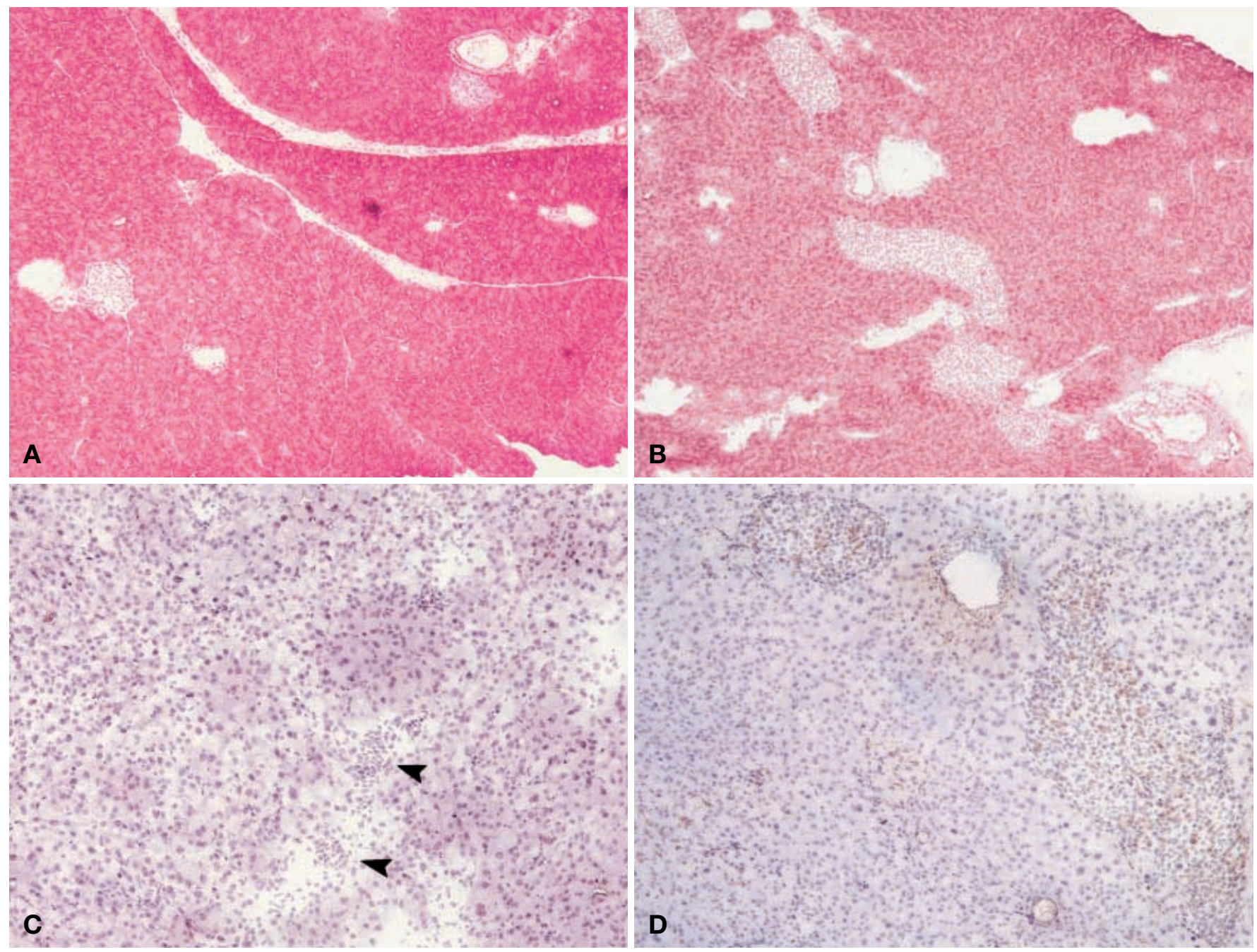

Fig. 2 A-D. Histopathology of pancreata from STZ-treated mice. Animals were killed at day 45 after STZ injection. (A, C) MLDSTZ-injected IRF-1 ${ }^{-/},(\mathbf{B}, \mathbf{D})$ MLDSTZ-injected wild type $\mathrm{C} 57 \mathrm{Bl} / 6$ control mice. Haematoxylin and eosin $(\mathbf{A}, \mathbf{B})$, insulin staining $(\mathbf{C}, \mathbf{D})$. Magnification: $\times 50(\mathbf{A}-\mathbf{B}), \times 100(\mathbf{C}-\mathbf{D})$. Note the severe depletion of insulin positive beta cells (in the few small residual islets) of the pancreata of STZ-treated IRF-1 ${ }^{-/-}$mice as compared to their respective $\mathrm{C} 57 \mathrm{Bl} / 6$ controls

other hand, insulin content of pancreata from diabetic IRF- $1^{-/}$mice was significantly decreased compared with $\mathrm{C} 57 \mathrm{Bl} / 6$ control mice $(p<0.05)$, indicating a more important destruction of insulin-producing beta cells in IRF-1 ${ }^{-/-}$mice (Table 1 ).

Islet allograft survival. To evaluate the effect of a global (IFN- $\gamma \mathrm{R}^{-/-}$), or selective (IRF-1 ${ }^{-/}$), disruption of IFN- $\gamma$ signalling on sensitivity of the islets to allograft rejection, we transplanted either IFN- $\gamma \mathrm{R}^{-/-}$or IRF- $1^{-/-}$islets and their respective control islets in alloxan-diabetic BALB/c mice. In the absence of the IFN- $\gamma$ receptor $(n=8)$, islet allograft survival was comparable to that observed in islets from $129 / \mathrm{Sv} / \mathrm{Ev}$

control donors $(n=9) \quad(12.0 \pm 1.9$ days vs $12.9 \pm$ 2.3 days, NS) (Fig. 3). On the other hand, islets from IRF-1 ${ }^{-/}$donors transplanted to alloxan-diabetic $\mathrm{BALB} / \mathrm{c}$ mice $(n=9)$ had a significantly reduced survival time than the $\mathrm{C} 57 \mathrm{Bl} / 6$ control islets $(n=9)$ $(9.1 \pm 2.0$ days vs $13.1 \pm 1.5$ days, $p<0.003)$ (Fig. 3 ), indicating an increased susceptibility of the IRF-1-1islets to immune-mediated destruction.

To investigate whether the more rapid rejection of IRF-1 $1^{-/}$islets was not due to a higher expression of inflammatory cytokines induced in $\mathrm{BALB} / \mathrm{c}$ mice by these islets, we analysed the patterns of mRNA expression of IL- $1 \beta$, TNF- $\alpha$, IFN- $\gamma$, and iNOS in the islet grafts of IFN- $\gamma \mathrm{R}^{-{ }^{-}}$, IRF-1 $1^{-/-}$and respective control mice at day 2 post transplantation ( $n=4$ per group) and at the time of graft rejection ( $n=8-9$ per group). No differences were observed between the cytokine profiles present in the IRF-1 $1^{-/}$and their control C57Bl/6 islet grafts. As expected, no significant differences were observed between the inflammatory cytokine patterns or iNOS mRNA expression in islet grafts of IFN- $\gamma \mathrm{R}^{-/-}$and corresponding $129 / \mathrm{Sv} / \mathrm{Ev}$ control mice (Fig.4A,B). Similar results were obtained for IL-6 mRNA expression in islet grafts (data not 

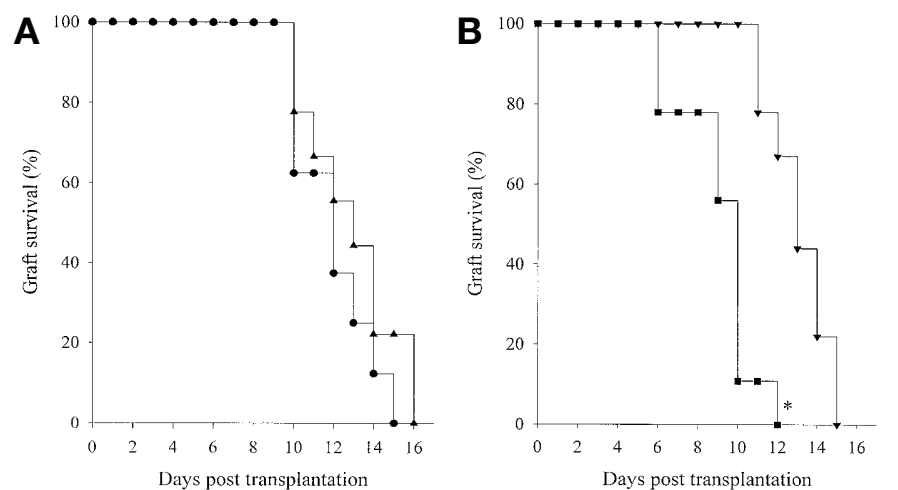

Fig. 3 A, B. Survival of allogeneic islets of (A) IFN $-\gamma \mathrm{R}^{-/-}(n=8$, $\mathbf{O})$ and $129 / \mathrm{Sv} / \mathrm{Ev}(n=9, \mathbf{\Delta})$ mice; $(\mathbf{B}) \operatorname{IRF}^{-1 /}(n=9, \mathbf{\square})$ and $\mathrm{C} 57 \mathrm{Bl} / 6(n=9, \boldsymbol{\nabla})$ mice in alloxan-diabetic BALB/c mice. Rejection was defined as a return to hyperglycaemia $\left(>11.0 \mathrm{mmol} / \mathrm{l}\right.$ ) after a period of normoglycaemia. ${ }^{*} p<0.003$ vs $\mathrm{C} 57 \mathrm{Bl} / 6$ mice. Note the faster destruction of IRF-1 ${ }^{-/}$islet grafts compared to $\mathrm{C} 57 \mathrm{Bl} / 6$ control islets in alloxan-diabetic $\mathrm{BALB} / \mathrm{c}$ mice

shown). These observations show that it is not likely that the faster destruction of IRF-1 $1^{-/-}$islets is caused by a more vigorous inflammatory response.

\section{Discussion}

There is increasing evidence that cytokines, such as IL- $1 \beta$, TNF- $\alpha$ and IFN- $\gamma$, secreted by infiltrating immune cells and free radicals are effector molecules involved in beta-cell dysfunction and damage in Type I diabetes [3]. Many of the cytokine-induced effects involved in inhibition of beta-cell function and beta-cell destruction are regulated at the transcriptional level. We have examined the effects of a global disruption of IFN- $\gamma$ signalling or a selective disruption of the IRF-1 pathway, on beta-cell sensitivity to immune destruction in vivo. In vitro, full IFN- $\gamma$ receptor knockout islets are resistant to cytokine-induced damage, as suggested by a near complete reduction in iNOS and MHC-I mRNA expression after a $24 \mathrm{~h}$ exposure to IL- $1 \beta+$ IFN- $\gamma$, as compared with wild-type control islets (Eizirik, unpublished data). Our in vivo data, however, show that absence of the IFN- $\gamma$ receptor at the beta-cell level does not reduce the rate of MLDSTZ-diabetes development. Moreover, our islet transplantation data illustrate that $\beta$-cell-IFN- $\gamma$ receptor deficiency has no protective effect on the outcome of islet allograft survival. Together, these data suggest that IFN- $\gamma$ signal transduction at the beta-cell level does not play a major role in immune-mediated betacell destruction in vivo. These data are consistent with a previous report showing that transgenic NOD mice with a mutant IFN- $\gamma$ receptor on their pancreatic islet cells have a similar rate of diabetes progression as wild-type controls [28]. These observations suggest that, in the absence of IFN- $\gamma$ signal transduction, the immune system utilizes other mechanisms to damage mouse beta-cells. Of note, IFN- $\gamma$, in combination with IL- $1 \beta$, is required to induce death of human islet cells [9], whereas IL- $1 \beta$ alone is sufficient to kill rat islet cells $[1,5]$. Thus, it is conceivable that IFN- $\gamma$ plays a more relevant role for human than for mouse betacell death in autoimmune diabetes.

We have previously observed a reduction in iNOS expression, nitric oxide formation and islet cell death in whole islet cells from mice with a selective disruption of the IRF-1 gene [22]. On the other hand, lack of IRF-1 gene expression did not protect FACS-purified beta cells against cytokine-induced cell death [22]. These data suggest that IRF-1 expression, probably in the non-beta-cells present in whole islets, is involved in cytokine-induced islet cell damage. Surprisingly, we observed that the absence of the IRF-1 gene in pancreatic islets in vivo promotes MLDSTZ-induced diabetes and accelerates destruction of beta cells in an allogeneic setting. These conflicting data cannot be attributed to more vigorous inflammatory responses elicited in vivo by the lack of beta-cell IRF-1 expression, since there were no differences in pro-inflammatory cytokine expression patterns and

Table 1. Evaluation of pancreatic insulin content in multiple low-dose streptozotocin-(MLDSTZ)-treated IFN- $\gamma \mathrm{R}^{-/-}$, IRF-1 ${ }^{-/-}$and respective control mice (immunohistochemistry and ELISA)

\begin{tabular}{|c|c|c|c|c|c|c|}
\hline \multirow[t]{2}{*}{ Strain } & \multicolumn{5}{|c|}{ Number of islets with respective beta-cell fraction (\%) } & \multirow{2}{*}{$\begin{array}{l}\text { Pancreatic insulin content } \\
(\mathrm{pmol} / \mathrm{mg})\end{array}$} \\
\hline & $\begin{array}{l}>80 \\
(\% \text { in }\end{array}$ & \multicolumn{4}{|c|}{ (\% insulin-positivity of islet surface) } & \\
\hline$\overline{\mathrm{IFN}-} \gamma \mathrm{R}^{-/-}$ & 0 & 5 & 18 & 5 & 72 & $1.024 \pm 0.307$ \\
\hline $129 / \mathrm{Sv} / \mathrm{Ev}$ & 0 & 11 & 23 & 6 & 60 & $1.656 \pm 0.608$ \\
\hline $\mathrm{IRF}-1^{-/-}$ & 0 & 0 & 3 & 11 & $86^{\mathrm{a}}$ & $0.566 \pm 0.191^{\mathrm{b}}$ \\
\hline $\mathrm{C} 57 \mathrm{Bl} / 6$ & 2 & 9 & 13 & 14 & 62 & $1.118 \pm 0.882$ \\
\hline
\end{tabular}

MLDSTZ-diabetes was induced in male mice as described in materials and methods. Histological examination of pancreata from IFN $-\gamma \mathrm{R}^{-/-}$and $129 / \mathrm{Sv} / \mathrm{Ev}$ mice showed a similar decrease in islet beta-cell fraction, while IRF-1/- pancreata had a higher depletion of their beta-cell fraction 45 days post STZ treatment compared with STZ-treated control C57Bl/6 mice. ${ }^{a} p<0.01$ vs STZ-treated C57B1/6 control mice.
Insulin content was also determined by ELISA. Pancreatic insulin content in control mice (not treated with STZ) is in the range of $14.383 \pm 6.969 \mathrm{pmol}$ insulin $/ \mathrm{mg}$ tissue. ${ }^{\mathrm{b}} p<0.05$ vs STZ-treated C57Bl/6 control mice 

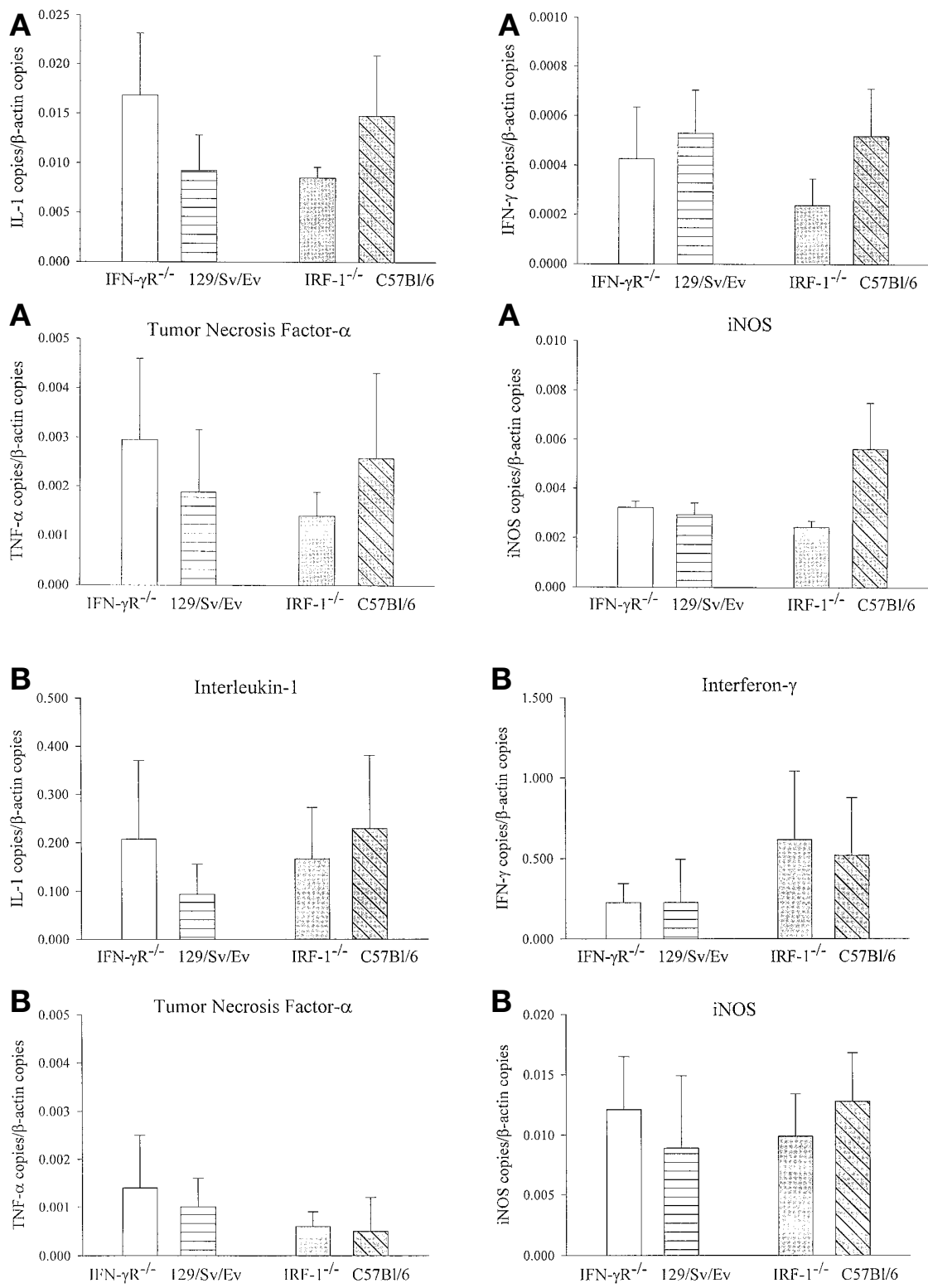

Fig. 4A, B. Real time RT-PCR analysis of cytokine mRNA patterns in islet transplants into alloxan-treated mice at day 2 post transplantation $(\mathbf{A})$ and at the time of graft rejection $(\mathbf{B})$. Islets were isolated from IFN- $\gamma \mathrm{R}^{-/-} ; \mathrm{IRF}-1^{-/-}$and respective control mice, and transplanted into alloxan-diabetic BALB/c mice. No differences in pro-inflammatory cytokine expression or iNOS mRNA were noted between the different experimental groups. Of note, however, is the much lower global expression pattern at day 2 post transplantation than at day of rejection (2-100 times lower)

iNOS mRNA levels between knockout and respective wild type control islet grafts. These data suggest that disruption of the IRF-1 gene in pancreatic islets increases susceptibility to in vivo immune beta-cell destruction.

Although inflammatory cytokines, such as TNF- $\alpha$ and IFN- $\gamma$, are clear mediators of beta-cell destruc-

tion in vitro, their role in beta-cell killing in in vivo models of Type I diabetes is less clear. Accelerated models of diabetes generated by transgenic expression of cytokines by islet beta cells have provided evidence that IFN- $\gamma$ is not sufficient to cause complete destruction of pancreatic beta cells in vivo because transgenic mice, expressing IFN- $\gamma$ under the control of the glucagon promotor do not have insulitis nor diabetes [29]. On the other hand, TNF- $\alpha$ has been more strongly implicated in the susceptibility to Type I diabetes, since mice with a transgenic expression of TNF- $\alpha$ in their beta cells are prone to the development of autoimmune diabetes. Indeed, TNF- $\alpha$-NOD mice develop an accelerated form of diabetes through a more vigorous infiltration of the islets by immune cells [30].

These findings, together with our data emphasise that caution is required when extrapolating observations of effects of cytokines on beta cells observed in 
vitro to a possible role in the pathogenesis of Type I diabetes. Most in vitro studies focus on the destructive properties of the cytokines as mediators of betacell damage, but recent data suggest that, under specific conditions, cytokines can also protect beta cells against a subsequent assault [31]. Whether the cytokines produced by islet-infiltrating macrophages and T cells are "directly" destructive to beta cells in vivo remains to be elucidated. In vivo, other destructive processes such as direct killing of beta cells by CD8 + cytotoxic cells, might also play an important role [32]. Moreover, during the in vivo immune response there is a mixture of endocrine and immune cells, some with membrane-bound cytokines, in close proximity. This can lead to a different outcome than the one observed in vitro, where pure beta cells are exposed to soluble recombinant cytokines.

Our data point towards a dual role for the IFN- $\gamma$ signalling pathway in immune-mediated beta-cell destruction, with possibly a protective role for IRF-1. Interferon- $\gamma$-induced STAT- $1 \alpha$ interacts directly and indirectly, through other transcription factors such as IRF-1, with IFN- $\gamma$-inducible genes such as iNOS [17, 33]. Because in IRF-1 $1^{-/}$mice the IRF-1 arm is knocked out, IFN- $\gamma$-induced STAT- $1 \alpha$ will only induce iNOS expression by direct GAS binding. The present observation that the absence of IRF-1, but not of IFN- $\gamma$ receptor expression leads to a more severe and faster immune-mediated beta-cell destruction, suggests that IFN- $\gamma$ induces beta-cell damaging (through STAT$1 \alpha$ ) and beta-cell protective (through IRF-1) mechanisms. In this context, it is of interest to identify these anti-survival and pro-survival genes, regulated by the transcription factors STAT- $1 \alpha$ and IRF-1.

We conclude that in contrast to the in vitro situation full or selective destruction of the IFN- $\gamma$ signalling pathways in pancreatic islet cells cannot protect beta cells from immune destruction in vivo. Our data indicate that IFN- $\gamma$ by itself is redundant for immune-mediated beta-cell killing and even generates dual effects since IRF-1 gene disruption in islets of Langerhans increases sensitivity to immune-mediated beta-cell destruction in vivo.

Acknowledgements. We thank D. Valckx and J. Depovere for their expert technical assistance and J. Laureys for all animal surgery. This work was supported by grants of the Flemish Research Foundation (FWO G021699), the Belgium National Ministry of Science (IUAP P4/21), the "onderzoeksraad" of the University of Leuven (GOA 99/10) and the Juvenile Diabetes Foundation International.

\section{References}

1. Mandrup-Poulsen T (1996) The role of interleukin-1 in the pathogenesis of IDDM. Diabetologia 39: 1005-1029

2. Eiririk DL, Flodström M, Karlsen AE, Welsh N (1996) The harmony of the spheres: inducible nitric oxide synthase and related genes in pancreatic beta cells. Diabetologia 39: 875-890

3. Rabinovitch A (1998) An update on cytokines in the pathogenesis of insulin-dependent diabetes mellitus. Diabetes Metab Rev 14: 129-151

4. McDaniel ML, Kwon G, Hill JR, Marshall CA, Corbett JA (1996) Cytokines and nitric oxide in islet inflammation and diabetes. Proc Soc Exp Biol Med 211: 24-32

5. Eizirik DL, Pavlovic D (1997) Is there a role for nitric oxide in $\beta$ cell dysfunction and damage in IDDM? Diabetes Metab Rev 13: 293-307

6. Rabinovitch A, Suarez-Pinzon WL, Sorenson O, Bleackley RC (1996) Inducible nitric oxide synthase (iNOS) in pancreatic islet of nonobese diabetic mice: Identification of iNOS-expressing cells and relationship to cytokines in the islets. Endocrinology 137: 2093-2099

7. Welsh N, Eizirik DL, Bendtzen K, Sandler S (1991) Interleukin-1-induced nitric oxide production in isolated rat pancreatic islets requires gene transcription and may lead to inhibition of the Krebs cycle enzyme aconitase. Endocrinology 129: 3167-3173

8. Delaney CA, Green MHL, Lowe JE, Green IC (1993) Endogenous nitric oxide induced by interleukin- $1 \beta$ in rat islets of Langerhans and HIT-T15 cells causes significant DNA damage as measured by the "comet" assay. FEBS Lett 333: 291-295

9. Delaney CA, Pavlovic D, Hoorens A, Pipeleers D, Eizirik DL (1997) Cytokines induce deoxyribonucleic acid strand breaks and apoptosis in human pancreatic islet cells. Endocrinology 138: 2610-2614

10. Moncada S (1999) Nitric oxide: discovery and impact on clinical medicine. J R Soc Med 92: 164-169

11. Ravinovitch A, Suarez-Pinzon WL, Sorenson O, Bleacley RC, Power RF (1995) IFN-gamma gene expression in pancreatic-islet-infiltrating mononuclear cells correlates with autoimmune diabetes in nonobese diabetic mice. J Immunol 154: 4874-4882

12. Debray-Sachs M, Carnaud C, Boitard C et al. (1991) Prevention of diabetes in NOD mice treated with antibody to murine IFN-gamma. J Autoimmun 4: 237-248

13. Boehm U, Klamp T, Groot M, Howard JC (1997) Cellular responses to interferon- $\gamma$. Annu Rev Immunol 15: 749-795

14. Leonard WJ, O'Shea JJ (1998) JAKS and STATS: biological implications. Annu Rev Immunol 16: 293-332

15. Mamane Y, Heylbroeck C, Génin P et al. (1999) Interferon regulatory factors: the next generation. Gene 237: 1-14

16. Flodström M, Eizirik DL (1997) Interferon- $\gamma$-induced interferon regulatory factor-1 (IRF-1) expression in rodent and human islet cells precedes nitric oxide production. Endocrinology 138: 2747-2753

17. Darville MI, Eizirik DL (1998) Regulation by cytokines of the inducible nitric oxide synthase promotor in insulin producing cells. Diabetologia 41: 1101-1108

18. Tamura T, Ishihara M, Lamphier MS et al. (1997) DNA damage-induced apoptosis and Ice gene induction in mitogenically activated $\mathrm{T}$ lymphocytes require IRF-1. Leukemia 11: 439-440

19. Taki S, Sato T, Ogasawara K et al. (1997) Multistage regulation of Th1-Type immune responses by the transcription factor IRF-1. Immunity 6: 673-679

20. Lohoff M, Ferrick D, Mittrucker HW et al. (1997) Interferon regulatory factor- 1 is required for a $\mathrm{T}$ helper 1 immune response in vivo. Immunity 6: 681-689

21. Matsuyama T, Kimura T, Kitagawa M et al. (1993) Targeted disruption of IRF-1 and IRF-2 results in abnormal type I IFN gene induction and aberrant lymphocyte development. Cell 75: 83-97 
22. Pavlovic D, Chen M-C, Gysemans CA, Mathieu C, Eizirik DL (1999) The role of interferon regulatory factor-1 in cytokine-induced mRNA expression and cell death in murine pancreatic $\beta$ cells. Eur Cytokine Netw 10: 403-411

23. Kolb H (1987) Mouse models of insulin dependent diabetes: low-dose streptozotocin-induced diabetes and nonobese diabetic (NOD) mice. Diabetes Metab Rev 3: 751-778

24. Casteels K, Waer M, Laureys J et al. (1998) Prevention of autoimmune destruction of syngeneic islet grafts in spontaneously diabetic nonobese diabetic mice by a combination of a vitamin $\mathrm{D}_{3}$ analogue and cyclosporine. Transplantation 65: $1225-1232$

25. Mathieu C, Laureys J, Sobis H, Vandeputte M, Waer M, Bouillon R (1992) 1,25-dihydroxyvitamin $\mathrm{D}_{3}$ prevents insulitis in NOD mice. Diabetes 41: 1491-1495

26. Gysemans C, Waer M, Laureys J et al. (2000) Islet xenograft destruction in hu-PBL-severe combined immunodeficient (SCID) mouse necessitates preactivation of human immune cells. Clin Exp Immunol 121: 557-565

27. Overbergh L, Valckx D, Waer M, Mathieu C (1999) Quantification of murine cytokine mRNAs using real time quantitative reverse transcriptase PCR. Cytokine 11: 305-312
28. Thomas HE, Parker JL, Schreiber RD, Kay TWH (1998) IFN- $\gamma$ action on pancreatic beta cells causes class I MHC upregulation but not diabetes. J Clin Invest 102: 1249-1257

29. Yamaoka T, Yano M, Idehare C et al. (1999) Apoptosis and remodelling of beta cells by paracrine interferon-gamma without insulitis in transgenic mice. Diabetologia 42: 566-573

30. Green EA, Flavell RA (1999) Tumor necrosis factor- $\alpha$ and the progression of diabetes in non-obese diabetic mice. Immunol Rev 169: 11-22

31. Ling Z, Van de Casteele M, Eizirik DL, Pipeleers DG (2000) Interleukin-1beta-induced alteration in a beta-cell phenotype can reduce cellular sensitivity to conditions that cause necrosis but not to cytokine-induced apoptosis. Diabetes 49: 340-345

32. Vizler C, Bercovici N, Cornet A, Cambouris C, Liblau RS (1999) Role of autoreactive CD8 + T cells in organ-specific autoimmune diseases: insights form transgenic mouse models. Immunol Rev 169: 81-92

33. Heitmeier MR, Scarim AL, Corbett JA (1999) Prolonged STAT1 activation is associated with IFN- $\gamma$ priming for interleukin-1-induced inducible nitric-oxide synthase expression by islets of Langerhans. J Biol Chem 274: 29266-29273 